\title{
Between independence and autonomous adaptation: The Europeanization of television regulation in non-EU member states
}

\author{
Puppis, Manuel
}

\begin{abstract}
Television regulation is increasingly Europeanized. While the transposition of community law into national legislation in EU member states has been widely discussed, scholarly attention is less frequently devoted to the Europeanization of non-member states. This paper investigates how television regulation in non-EU members has been influenced by European audiovisual policy since the liberalization of broadcasting. Focusing on the case of Switzerland and putting it into a wider context, changes in television regulation and their connection to the European level were analyzed by performing a qualitative document analysis. Results indicate that the degree of Europeanization in Switzerland differs remarkably from other non-member states like Norway. While advertising regulation was brought in line with less-strict EU directives, a public value test or compliance with state aid rules were not even discussed. Yet similar to other non-members, rules were adopted without having a say in their development.
\end{abstract}

DOI: https://doi.org/10.1515/commun-2012-0022

Posted at the Zurich Open Repository and Archive, University of Zurich

ZORA URL: https://doi.org/10.5167/uzh-66649

Journal Article

Published Version

Originally published at:

Puppis, Manuel (2012). Between independence and autonomous adaptation: The Europeanization of television regulation in non-EU member states. Communications: The European Journal of Communication Research, 37(4):393-416.

DOI: https://doi.org/10.1515/commun-2012-0022 
Manuel Puppis

\title{
Between independence and autonomous adaptation: The Europeanization of television regulation in non-EU member states
}

\begin{abstract}
Television regulation is increasingly Europeanized. While the transposition of community law into national legislation in EU member states has been widely discussed, scholarly attention is less frequently devoted to the Europeanization of non-member states. This paper investigates how television regulation in non-EU members has been influenced by European audiovisual policy since the liberalization of broadcasting. Focusing on the case of Switzerland and putting it into a wider context, changes in television regulation and their connection to the European level were analyzed by performing a qualitative document analysis. Results indicate that the degree of Europeanization in Switzerland differs remarkably from other non-member states like Norway. While advertising regulation was brought in line with less-strict EU directives, a public value test or compliance with state aid rules were not even discussed. Yet similar to other non-members, rules were adopted without having a say in their development.
\end{abstract}

Keywords: European Union, European Economic Area, non-EU member states, Switzerland, television, regulation, media policy

Manuel Puppis: e-mail: m.puppis@ipmz.uzh.ch

\section{Introduction}

Starting in the 1980s, European broadcasting markets were liberalized, putting an end to the predominant position public service broadcasting had in most countries. At the same time, also due to new distribution technologies, a new era of transfrontier television began and allowed for the circumvention of domestic regulation (Dyson and Humphreys, 1989; Hallin and Mancini, 2004, p. 275; Humphreys, 1996, pp. 164-170). As a response, both the European Union 
(EU) and the Council of Europe (CoE) became active in television regulation. Existing research in political science reveals that Europeanization is not limited to member states but affects non-EU member states as well (e.g., Sciarini, Fischer, and Nicolet, 2004).

However, while the EU's audiovisual policy and its influence on national legislation of member states have been widely discussed (Harcourt, 2005; Harrison and Woods, 2007; Levy, 1999; Michalis, 2007; Wheeler, 2004), scholarly attention is less frequently devoted to processes of Europeanization of non-member states. With the exception of the new ex-ante test for public service broadcasting in Norway (Moe, 2010), such processes have not yet been explored.

Thus, the present paper raises the question of how television regulation in non-EU member states was Europeanized. Taking account of existing research that shows that Europeanization affects non-members to varying degrees (Egebert and Trondal, 1999; Kux and Sverdrup, 2000), this paper focuses on the case of Switzerland. In contrast to acceding countries and members of the European Economic Area (EEA), the country has no obligation to transpose community law. The case study thus promises important insights into similarities and differences with respect to Europeanization. Based on a qualitative analysis of documents (legal documents, explanatory notes, government reports, parliamentary debates), changes in television regulation and their connection to the European level were looked at. Results indicate that the degree of Europeanization in Switzerland differs remarkably from other non-member states: While advertising regulation was reluctantly brought in line with less-strict EU directives, the introduction of a public value test and compliance with European state aid rules proved to be non-issues. Yet similar to EEA members, rules were adopted without having a say in their development.

In what follows, the ways Europeanization affects television regulation in non-member states of the EU are discussed. Then, after shortly dealing with the methods employed, the results of the case study are presented. Subsequently, the final section discusses the results and puts them into a wider context before coming to a conclusion.

\section{Europeanization, television and non-EU member states}

Regional integration gave rise to a whole new level of governance in Europe. The concept of Europeanization denotes the partial replacement of national policy-making by supranationalism and it necessitates the transposition of com- 
munity law into national legislation of member states (Kux and Sverdrup, 2000, p. 238).

\section{European governance of transfrontier television}

In the area of television regulation, Europeanization is of importance as well because liberalization and new distribution technologies brought about a new era of transfrontier television: Operating from the most favorable regulatory base, television stations could access more-strictly regulated markets and circumvent domestic regulation (Dyson and Humphreys, 1989; Hallin and Mancini, 2004, p. 275; Harrison and Woods, 2007, pp. 97-98, 192-193; Humphreys, 1996, p. 170). Transfrontier television plays an even bigger role in small media systems with a next-door giant neighbor sharing the same language. On the one hand, small market size results in very costly media production and limits advertising revenues, thus hindering the development of a domestic television industry. On the other hand, overspilling foreign channels of the same language hold a strong market position, involving fierce competition for domestic public and commercial channels alike (Bonfadelli and Meier, 1994, pp. 71-72; Burgelman and Pauwels, 1992, pp.173-174; Meier and Trappel, 1992, pp.130-135; Puppis, 2009, pp. 10-11; Trappel, 1991, pp. 358-363). Competition is not limited to audience markets, as advertising revenues flow out to commercial broadcasters abroad as well by way of so-called "advertising windows" on foreign channels directed at domestic viewers (Bonfadelli and Meier, 1994, pp. 82-83; Puppis, 2009, pp. 11-12; Siegert, 2006, pp. 198-199).

In response to this increasing importance of cross-border television, which undermined national regulation, "attempts were made by the European countries to compensate for this by establishing transnational systems of governance" (Syvertsen, 2003, p. 168). Both the Council of Europe (CoE) and the European Union (EU) became active in the late 1980s. The CoE's "European Convention on Transfrontier Television" (ECTT) of 1989 promotes the free circulation of television programs provided that they adhere to commonly agreed standards and also served as a basis for the preparation of the EU's "Television without Frontiers" (TWF) directive. This directive, which entered into force in 1989, regulates both transfrontier and domestic television, thus realizing a common market in television (Harrison and Woods, 2007, pp.97-98, 173-174; Michalis, 2007, pp. 157-161; Wheeler, 2004, pp. 354-357). While the TWF directive establishes that television stations are subject to their state of transmission's regulation only and that member states have to ensure freedom of reception and retransmission of stations from other member states, it also stipulates minimum 
standards for television operations in all member states. Moreover, it allows for reverse discrimination, that is, stricter domestic regulation. In addition to the TWF directive and its successor, the "Audiovisual Media Services" (AVMS) directive of 2007, broadcasting regulation is also subject to EU competition policy (Harrison and Woods, 2007, pp. 290-311; Moe, 2010, pp. 207-210).

\section{The Europeanization of non-EU member states}

The influence of the EU on domestic policies is not restricted to member states but affects non-EU member states as well: “Adjacent countries and/or countries maintaining intensive political or economic relations with the EU also may converge to these European standards" (Schneider and Werle, 2007, p. 276). Due to their geographical location and the importance of the common market for their economies, these countries are highly influenced by European integration (Sciarini et al., 2004, p. 354). This is true for countries like Norway, Switzerland or the Central and Eastern European states that became EU members later on. However, Europeanization affects non-members to varying degrees as their institutional ties with the EU differ. Consequently, the dichotomy of membership/non-membership needs to be substituted by a more differentiated view on integration that accounts for different forms of associate or quasi-membership (Egebert and Trondal, 1999, p. 134; Kux and Sverdrup, 2000, p. 239). A distinction can be made between acceding countries, EEA countries and Switzerland (Sciarini et al., 2004, pp. 354-355).

Towards acceding countries (e.g., in Central and Eastern Europe), the EU pursues a policy of conditionality under which it provides incentives for compliance with its policies. Pressure for adaptation arises from the prospect of full membership (Schimmelfennig and Sedelmeier, 2004, pp. 661-662; Sciarini et al., 2004, p. 354). Thus, both state aid rules and the AVMS directive have been transferred to soon-to-be members.

The EFTA countries that joined the European Economic Area (EEA; namely Norway, Iceland and Liechtenstein) are required to constantly align with the EU acquis communautaire in the fields covered by the agreement. This includes EU competition regulation as well as audio-visual and cultural policy, for example, the AVMS directive or the MEDIA support program for the audio-visual industry (Kux and Sverdrup, 2000, p. 245; Lavenex, Lehmkuhl and Wichman, 2009, p. 817; Moe, 2010, p. 210; Syvertsen, 2003, p. 156). The EEA agreement "created a permanent stream of decisions from the EU system to the EEA countries" (Kux and Sverdrup, 2000, p. 241), and it can be argued that EEA countries are Europeanized to the same extent as full EU members when it comes to the 
transposition of EU regulations (Egebert and Trondal, 1999, p. 134; Lavenex et al., 2009, p. 817). Norway, for instance, recently implemented an ex-ante test regarding the public service broadcaster's new media services (Moe, 2010). Given that EEA states are formally excluded from EU decision-making, some have called this quasi-automatic transfer of EU regulations semi-colonial (Lavenex et al., 2009, p. 818).

In contrast to acceding countries and EEA members, countries like Switzerland have no legal obligation to transpose EU directives into national legislation (Sciarini et al., 2004, p. 354). Nevertheless, Switzerland adjusted its regulatory framework in many policy areas to EU rules (Mach, Häusermann, and Papadopoulos, 2003, p. 302). Generally, such Europeanization without obligation may take two different forms (Sciarini et al., 2004, pp. 354-355): First, direct Europeanization refers to transmission mechanisms resulting from international negotiations. The so-called "bilateral agreements" between Switzerland and the EU amount to the incorporation of EU regulations into Swiss law in selected policy areas (Lavenex et al., 2009, p. 819). They not only grant Switzerland access to the common market but also provide a basis for cooperation in areas like research, security or culture. For instance, the "MEDIA Plus" and "MEDIA 2007" agreements cover the country's participation in the MEDIA support programs for the audiovisual industry. Moreover, Switzerland is also a party to the ECTT, which might have necessitated the alignment of pre-existing regulation. Second, indirect Europeanization occurs without formal negotiations and means that a non-member state unilaterally adapts to existing European rules. In Switzerland, this so-called “autonomous adaptation” (autonomer Nachvollzug) involves an evaluation of EU-compatibility of each new piece of legislation (Kux and Sverdrup, 2000, p. 251; Lavenex et al., 2009, p. 819). As with access to the common market, the Swiss economy has a strong interest in such compatibility in order to prevent discrimination of domestic companies.

\section{Research questions and propositions}

This overview emphasizes that the Europeanization of television regulation is not restricted to member states of the EU. Rather, the boundaries of the Union have become blurred (Kux and Sverdrup, 2000). As they have to adapt to the acquis communautaire, state aid rules, support programs for the audio-visual industry and minimum standards for linear and non-linear audio-visual services also apply to acceding countries and EEA members. The degree of Europeanization of Swiss television regulation and how it differs from the situation in 
other non-member states is less clear. The few existing studies in political science looking into the complex relationship between the EU and Switzerland did not analyze the television sector. However, the questions of how Swiss television regulation was influenced by European audiovisual policy in the last 25 years, how Europeanization differs from other non-member states, and whether direct or indirect Europeanization proved to be more important merit attention. After all, transfrontier television plays a significant role. Switzerland is a typical small state with three next-door giant neighbors sharing the same languages which results in a strong position of overspilling German, French and Italian TV channels in the Swiss television market.

As discussed above, Switzerland as a non-member of both the EU and the EEA has no obligation to adapt to the acquis communautaire (Sciarini et al., 2004, p. 354), and bilateral agreements play a minor role with respect to the media, covering only support programs for the audiovisual industry. And while Switzerland is a party to the ECTT, the convention contains only minimum standards, limiting its direct influence on national regulation. Thus, I first propose that direct Europeanization plays only a marginal role for television regulation in Switzerland.

In contrast, it can reasonably be expected that indirect Europeanization is highly important. While reverse discrimination is explicitly allowed in both the TWF directive and the ECTT, locational policy favors a leveling down to European minimum standards. In order to preserve the competitiveness of domestic broadcasting markets, one country after another imported deregulation (Dyson and Humphreys, 1989, pp. 142-143; Humphreys, 1996, pp. 164-170). Given the importance of advertising for commercial channels, I secondly posit that Switzerland autonomously adapted to European minimum standards with respect to advertising.

However, the revised AVMS directive of 2007 heavily liberalized advertising regulation in the EU while the corresponding revision of the ECTT was first stalled and then discontinued due to an intervention of the European Commission (Zeller and Ramsauer, 2010). Ever since, television stations in neighboring EU countries have to comply with less-rigid regulation than domestic stations. Consequently, it can be expected that the nature of indirect Europeanization changed and thus I thirdly propose that Switzerland, in order to maintain the competitiveness of its domestic television industry, autonomously adapted to the liberalized EU advertising regulations.

The following section will shortly discuss the methods employed before presenting the results of the empirical study. 


\section{Swiss television regulation and Europeanization}

In order to analyze the complex relationship between the European level and Switzerland with respect to television regulation, a qualitative analysis of documents was performed. Publicly available legal documents like acts, ordinances (decrees) and bills, accompanying dispatches and explanatory notes of the Federal Council (government) and the ministry (Federal Department of the Environment, Transport, Energy and Communications, DETEC) as well as minutes of parliamentary debates (official bulletin of the National Council and the Council of States) were collected and analyzed using a method of deductive content categorization (Mason, 2002; Mayring, 2007).

Specifically, categories were generated in terms of forms (direct/indirect) and source (EU/ECTT) of Europeanization. In addition, the development of Swiss television regulation was broken down into different phases. Since the introduction of the first Radio and Television Act (RTVA) 1991 and the corresponding Radio and Television Ordinance (RTVO) 1992, which officially liberalized broadcasting (phase 1), the Swiss legislation was amended and revised several times. It was adjusted after the failed accession to the EEA in 1993 (phase 2), to the revised ECTT and TWF directive in 1999 (phase 3) and to the "MEDIA Plus" treaty with the EU in 2006 (phase 4). The regulatory framework was revised completely with the new RTVA 2006 and RTVO 2007 (phase 5) which were then again adjusted in 2010 to both the "MEDIA 2007" treaty with the EU (phase 6) and the EU's AVMS directive (phase 7).

\section{Phase 1: The first radio and television law of 1991}

With the entering into force of the RTVA 1991 and the RTVO 1992 on April 1, 1992, there was for the first time a definitive regulatory framework for broadcasting. For long the public service broadcaster SRG SSR had a monopoly and Switzerland introduced private broadcasting only cautiously. Only in 1984, as a response to ever-more popular pirate radio stations, terrestrial advertisingfunded local radio and television stations were introduced as part of a pilot operation. The experiment was extended until the RTVA entered into force (Bonfadelli and Meier, 2007; Dumermuth, 2007, pp. 358-364; Künzler, 2009, pp.179-202, 251-277; Künzler and Schade, 2007, pp.98-99; Meier, 1993, pp. 209-210; Saxer, 1989, p. 29).

The radio and television bill as originally proposed by the Federal Council was rather strict. On the one hand, the government suggested upholding an existing ban on foreign channels that do not comply with Swiss advertising 
rules from cable networks (Federal Council, 1987, p. 745; RTV Bill 1987, Art. 48). Yet this provision proved untenable after the ratification of the ECTT. Thus, the bill was changed in order to allow for the cable distribution of foreign channels as long as they comply with the minimum standards of the ECTT (Federal Council, 1990, p. 938).

On the other hand, the bill envisioned advertising regulations that were partly stricter than the European rules of the TWF directive and the ECTT (Federal Council, 1990, pp. 939-940, 944). First, it was suggested to prohibit political and religious advertising as well as advertising for tobacco products, alcohol and prescription medications because of health and political reasons (Federal Council, 1987, pp. 713-714; RTV Bill 1987, Art.17(5)). Second, the government originally planned to prohibit commercial breaks (Federal Council, 1987, p. 722; RTV Bill 1987, Art.17(2)). Both positions were widely supported in a public consultation on a first draft of the bill (Federal Council, 1987, pp. 713-714).

In parliament, the ban of political and religious advertising proved to be uncontroversial. However, since both the ECTT and the TWF directive did not prohibit alcohol advertising, some members of parliament argued for an alignment to European rules in order create so-called gleich lange Spiesse or a level playing field. Nevertheless, a majority supported the ban (AB N 1989, pp. 16281633, 1638; RTVA 1991, Art.18(5); RTVO 1992, Art.14(1)). In contrast, the regulation of commercial breaks led to heated and lengthy debates. Proponents called for a level playing field. They argued that a ban would not only be counterproductive as it would constrain the competitiveness of Swiss broadcasters and lead to an outflow of advertising expenditures to foreign channels but also render the transmission of longer broadcasts in prime time economically unviable (AB N 1989, pp. 1593-1594, 1627; AB S 1990, pp. 581-582). Opponents compared commercial breaks to 'mental slaps in the face' and pointed out that the ECTT contains only minimum standards, thus allowing for reverse discrimination (AB N 1989, pp. 1632-1634; AB S 1990, p. 582; AB N 1991, p. 337). But even supporters of commercial breaks thought that European regulations went too far. The TWF directive and the ECTT stipulated that films longer than 45 minutes may be interrupted once for each period of 45 minutes; other programs may be interrupted every 20 minutes; news, documentaries, religious and children's programs may be interrupted every 20 minutes provided that they are longer than 30 minutes (Directive 89/552/EEC, Art.11; ECTT, Art. 14). Members of parliament proposed that only broadcasts longer than 90 minutes may be interrupted once (AB N 1989, p. 1635; AB S 1990, pp. 563, 568, 581). As a consequence, even the government changed its mind: Given the rapid change of broadcasting, it was argued that there was no scope for a Swiss exception. Instead, 'a middle course between adaptation and Alleingang' by way of a mod- 
est liberalization was now supported (AB S 1990, p. 583). Yet it took three readings and a conciliation conference between the two houses of parliament until this proposition was passed (RTVA 1991, Art.18(2); RTVO 1992, Art.11(2)).

Time limits for advertising were not regulated in the RTVA but decided upon by the Federal Council in the RTVO in order to be more flexible (Federal Council, 1987, p. 734; RTVA 1991, Art.18(3)). The adopted rules were identical with the ECTT and the TWF directive: The amount of advertising spots was limited to $15 \%$ of the daily transmission time ( $8 \%$ in public television); a limit of $20 \%$ applied to advertising spots and other forms of advertising taken together; such other forms of advertising were limited to an hour per day; and the amount of advertising spots within a given one-hour period was limited to 12 minutes (RTVO 1992, Art.12(1); Directive 89/552/EEC, Art. 18; ECTT, Art. 12).

Obviously, the Swiss law was stricter than the minimum standards contained in the TWF directive and the ECTT when it comes to commercial breaks as well as alcohol, political and religious advertising. Yet thanks to a special provision of the ECTT, these rules did not only apply to Swiss channels but also to advertising windows on foreign (mostly German and French) channels directed at Swiss viewers. Advertising windows were not allowed to circumvent Swiss regulation: As long as advertising regulation is not discriminating between domestic and foreign channels, "advertising and tele-shopping which are [...] directed to audiences in a single Party other than the transmitting Party shall not circumvent the television advertising and tele-shopping rules in that particular Party” (ECTT, Art. 16).

There were a few other adaptations of the bill to European regulations. First, the sponsorship rules in the bill (RTV Bill 1987, Art. 18) were changed in order to adopt the slightly stricter European rules (Federal Council, 1990, pp. 944-945; Directive 89/552/EEC, Art.17; ECTT, Art.17-18; RTVA 1991, Art. 19). Second, a new provision in accordance with the ECTT, that broadcasters have to take account of European productions, was added during parliamentary stage (AB N 1989, pp. 1644-1645; AB S 1990, p. 577; RTVA 1991, Art. 3(1)(f)). And finally, the RTVO was amended on January 1, 1994 with the provision that broadcasters have to wait for two years before airing a film after it was shown in cinema (ECTT, Art.10(4); Directive 89/552/EEC, Art. 7; RTVO 1992, Art. 19a as amended by AS 1993, p. 3357-3365).

Moreover, during parliamentary stage, the European Court of Human Rights (ECHR) pronounced a judgment that freedom of expression not only applies to the reception of television programs from direct-broadcasting satellites but also from telecommunications satellites (Case of Autronic AG v. Switzerland). As a consequence, the provision of the RTV bill that required authorization for the reception of television signals from telecommunications satellites and several 
provisions distinguishing between telecommunications and broadcasting satellites had to be changed (AB S 1990, pp. 575-576; AB N 1991, p. 335).

In sum, the RTVA was changed significantly from bill to act - not only because of direct Europeanization in order to ensure compliance with the new European minimum standards (ban from cable networks, freedom of reception, sponsoring rules, waiting period for films) but also voluntarily in order to avoid too strong reverse discrimination of domestic broadcasters (commercial breaks, time limits for advertising).

\section{Phase 2: Failed accession to the EEA agreement}

When Switzerland planned to accede to the EEA agreement in the early 1990s, various adjustments to the EU's regulatory framework were prepared. In broadcasting, membership in the EEA would have led to a participation in the "MEDIA 95" program and a transposition of the TWF directive. However, given the compatibility of the RTVA with European regulations, only minor adjustments would have been necessary. Specifically, discriminations of persons from EEA member states in licensing and must-carry regulations were to be abolished. Moreover, the preferential treatment of Swiss productions in TV programs was to be extended to European productions (Federal Council, 1992, pp. 627630; AB S 1992, p. 658; AB N 1992, p. 1972).

Yet the EEA agreement was rejected in a referendum in late 1992. The government decided not to dismiss all of the prepared legislative changes in order to reinvigorate the Swiss economy and to assure compatibility with EU regulations (Federal Council, 1993, p. 810). Regarding broadcasting, it was suggested to parliament to open the audiovisual market for foreign broadcasters by abolishing the discrimination of foreign persons when it comes to licensing and must-carry regulations. The preferential treatment of European productions was however made subject to a participation in the "MEDIA 95" program, which never happened. Parliament passed this indirect Europeanization without controversy (Federal Council, 1993, pp.861-862; AB S 1993, p.193; AB N 1993, p. 811; RTVA 1991, Art. 11, 26, 31, 35, 42 as amended by AS 1993, pp. 3354-3356).

\section{Phase 3: Adapting to the revised ECTT and TWF directive}

The revision of the TWF directive in 1997 and the ECTT in 1998 brought about several changes. First, teleshopping windows of up to three hours were now allowed, teleshopping spots were included in the existing time limits, and chan- 
nels exclusively devoted to teleshopping came under the regime as well (Directive 89/552/EEC as amended by Directive 97/36/EC, Art.18, 18a, 19; ECTT, Art. 12, 18bis). Second, the revised European rules dealt with the access of the public to events of major importance (Directive 89/552/EEC as amended by Directive 97/36/EC, Art.3a; ECTT, Art.9a). And third, the provision that broadcasters have to wait for two years before airing a film after it was shown in cinema was abolished (Directive 89/552/EEC as amended by Directive 97/36/EC, Art. 7; ECTT, Art. 10(4)).

In response, the Federal Council opted for an indirect Europeanization and amended the RTVO on August 1, 1999. It abolished the waiting period for films and adopted the provision granting access to major events but not the revised teleshopping regulations (Federal Council, 1999, pp. 1297-1301; RTVO 1997, Art. 20a, 21 as amended by AS 1999, pp. 1845-1847).

\section{Phase 4: Participation in the "MEDIA Plus" program}

The biggest adaptation to European regulations between 1991 and 2006 was related to the MEDIA support program for the audiovisual industry. Based on a new bilateral agreement between the European Community and Switzerland, the country was allowed to participate in the "MEDIA Plus" program.

However, non-member states may only participate in the MEDIA program if their regulation corresponds to the TWF directive. Since the only major difference between Swiss legislation and community law were the quotas for European and independent productions, Switzerland had to implement these quotas in 2006 (Federal Council, 2004, pp. 6000, 6054). All television stations (with the exception of local and regional ones) have to ensure, where practicable and by appropriate means, that at least $50 \%$ of their transmission time is reserved for Swiss or other European works and that at least $10 \%$ of their transmission time or at least $10 \%$ of their programming budget is reserved for Swiss and other European works by independent producers (Federal Council, 2004, pp. 6057, 6234-6236; MEDIA Plus Agreement, Appendix II; RTVA 1991, Art. 6 a as amended by AS 2006, pp. 1039-1040; RTVO 1997, Art. 20c as amended by AS 2006, pp. 959-960). This change proved to be uncontroversial in parliament (AB S 2004, p. 683; AB N 2004, p. 1920). Accordingly, Switzerland had to adapt to the TWF directive as a trade-off for the participation in the MEDIA program a first instance of direct Europeanization to community law. 


\section{Phase 5: The revised radio and television law of 2006}

In response to a changing environment, the Federal Council decided to revise the RTVA and the RTVO completely. The main thrust of the revision was to abolish the reverse discrimination of domestic private broadcasters and to 'free them from unnecessary regulatory constraints' (Federal Council, 2000a, p. 20). Accordingly, the government suggested leveling down Swiss advertising regulation to the minimum standards of the TWF directive and the ECTT (Federal Council, 2000a, p. 22; 2000b, pp. 13, 16, 51; 2002, pp.1592, 1597, 1614, 1623). First, the bill brought the regulation of commercial breaks in line with European regulations. However, in contrast to the TWF directive and the ECTT, it was suggested to prohibit breaks in children's programs. Second, the only remaining differences regarding time limits were eliminated by recognizing teleshopping spots and allowing teleshopping windows of up to three hours per day (RTV Bill 2002, Art. 11, 12, 15(2); Federal Council, 2002, pp. 1623, 1677-1679). In both cases, the stricter rules for public television were to remain unchanged. Finally, it was proposed to lift the ban on alcohol advertising. Initially, the Federal Council planned to uphold the ban because of prevention (Federal Council, 2000b, p. 52; RTV Draft 2000, Art.10(1)). Yet after a public consultation on a first draft of the bill, the government changed its mind and suggested to allow advertising for beer and wine but not for spirits on private channels (RTV Bill 2002, Art. 10(1); Federal Council, 2002, pp. 1623, 1675-1676). In contrast, political and religious advertising was still intended to be prohibited, albeit political advertising was now more narrowly defined in order to comply with an ECHR judgment (Federal Council, 2002, pp. 1623, 1676-1677; DETEC, 2007, pp. 10-11; Case of VgT Verein gegen Tierfabriken v. Switzerland).

The liberalization of advertising regulation was widely supported in parliament. The provisions dealing with commercial breaks and time limits were passed smoothly and the competency to decide on details was delegated to the Federal Council, who adopted the European minimum standards in the RTVO (RTVA 2006, Art.11, 13(2); RTVO 2007; Art. 18, 19, 22; DETEC, 2007, pp. 11, 13). Some members of parliament even suggested abolishing the ban on political and religious advertising. Yet a majority perceived political advertising as harmful to a well-functioning direct democracy and upheld the ban (AB N 2004, pp. 63-64; 2005, p. 1114; AB S 2005, p. 60; RTVA 2006, Art.10(1); RTVO 2007, Art. 17). It was mainly the liberalization of alcohol advertising that proved to be controversial. While proponents welcomed the equal treatment of foreign and domestic channels, opponents referred to youth protection and reminded their colleagues that advertising windows have to comply with Swiss advertising regulation thanks to the aforementioned special provision of the ECTT (AB N 2004, 
pp. 60-62; ECTT, Art.16). In the end, parliament wanted to prevent an outflow of advertising expenditure to advertising windows on foreign channels and permitted advertising for beer and wine on local and regional channels only (AB S 2005, p. 60; AB N 2005, p. 1114; RTVA 2006, Art.10(1), 14(2)). In the RTVO, the rules for the presentation of alcohol advertising were adapted to European standards (RTVO 2007, Art. 16; DETEC, 2007, p. 10).

Aside from Europeanizing advertising regulation, the new law also adopted the ECTT's provision that programs shall respect fundamental rights and human dignity (Federal Council, 2002, p.1668; ECTT, Art.7(1); RTVA 2006, Art. 4(1)) and provisions of the TWF directive (that are more detailed than the ones in the ECTT) dealing with the protection of minors (Federal Council, 2002, p. 1670; DETEC, 2007, p. 3; Directive 89/552/EEC as amended by Directive 97/ 36/EC, Art.22a; ECTT, Art.7(2); RTVA 2006, Art.5; RTVA 2007, Art.4). These changes did not cause any debates in parliament.

The revised RTVA and RTVO (which entered into force on April 1, 2007) demonstrate that there was no need to adapt Swiss regulation to the ECTT and community law. The liberalization of advertising regulation was a conscious and sovereign political decision in order to grant domestic broadcasters the same possibilities like foreign channels.

\section{Phase 6: Participation in the "MEDIA 2007" program}

When the "MEDIA Plus" support program expired at the end of 2006, Switzerland had to renegotiate a new bilateral agreement with the EU in order to be able to participate in the new "MEDIA 2007" program. Yet this time around, negotiations proved to be more difficult.

It became clear that the European Commission demanded that Switzerland not only adopt European quota regulations but also the TWF directive's provisions dealing with the access of the public to events of major importance and the state of transmission (or country of origin) principle (Federal Council, 2007, p. 6689). While quotas and access to major events were already implemented, adopting the state of transmission principle would override the ECTT's provision that advertising windows have to comply with Swiss regulation. That would allow them to circumvent the stronger Swiss regulation when it comes to alcohol, political and religious advertising. This was not only seen as a problem because of alcohol prevention and direct democracy but also as an economic discrimination of domestic channels (Federal Council, 2007, p. 6690). The agreement was put into force provisionally on September 1, 2007, but parliament sent it back to government for renegotiations (AB N 2007, pp. 1854-1859; AB S 2007, pp. 1013-1018). 
A year later, the government presented a slightly revised agreement. The European Commission was not willing to grant Switzerland an exception from the state of transmission principle. Instead, it was agreed that Switzerland (similar to the process described in Directive 2010/13/EU, Art. 4) could contact member states from which advertising windows non-compliant with Swiss regulation originate in order to achieve a mutually satisfactory solution (Federal Council, 2008, pp. 9111-9112; MEDIA 2007 Agreement, Appendix I, Art.1). The government was convinced that using this process the bans on spirits, political and religious advertising could be upheld for advertising windows. The chance to enforce a ban on advertising for wine and beer on advertising windows was however perceived to be unrealistic. In order to prevent a discrimination of domestic channels, government thus suggested abolishing the ban on wine and beer advertising for all Swiss channels, including public television (Federal Council, 2008, pp. 9112-9117). Parliament was divided. In lengthy debates (AB N 2009, pp. 877-880, 1578-1579; AB S 2009, pp. 233-238, 448-449, 915), opponents of alcohol advertising expressed their worries regarding prevention and the protection of minors while proponents argued against a discrimination of domestic channels: "Let's not score an own goal; let us at least grant a level playing field to Swiss broadcasters" (AB S 2009, p. 448). The two houses could not agree. It took three readings and a conciliation conference to adopt this liberalization of alcohol advertising. The liberalization entered into force on February 1, 2010 (RTVA 2006, Art. 10(1), 14(2), as amended by AS 2010, pp. 371372).

In order to guarantee the participation of Switzerland in the MEDIA support program, the country had to accept the state of transmission principle - a second instance of direct Europeanization to community law. However, the liberalization of advertising for beer and wine on national domestic channels was not demanded by the EU but simply influenced by the desire to avoid reverse discrimination.

\section{Phase 7: Dealing with the AVMS directive}

Even before the above-mentioned liberalization was passed, another round of deregulation of advertising rules started. In August 2009, the government proposed to revise the RTVO in response to the EU's new AVMS directive. This directive brought about a liberalization of advertising regulation in EU member states. And since advertising windows on foreign channels are no longer subject to Swiss regulation but to the regulation in their respective countries of origin, they would benefit from less-rigid regulations than domestic channels. The 
argument essentially was that a liberalization of advertising regulations was necessary to counteract this emerging disadvantage for domestic channels (DETEC, 2009, p. 1).

After a public consultation, the government liberalized existing regulations: First, the provision allowing isolated advertising spots was adopted (Directive 2010/13/EU, Art. 19(2); RTVO 2007, Art. 18(1) as amended by AS 2010, pp. 965972). Second, the regulation of commercial breaks was leveled down to the new European minimum standards. For most programs, no limitations exist anymore. Films and news may be interrupted for each period of at least 30 minutes. No breaks are allowed during religious services. However, differing from the AVMS directive, Switzerland upholds the prohibition to insert advertising during children's programs (Directive 2010/13/EU, Art.20; RTVO 2007, Art. 18 as amended by AS 2010, pp. 965-972). Third, the time limits for advertising were eased. As in the AVMS directive, the proportion of advertising spots and teleshopping spots should not exceed $20 \%$ per hour. The time limits for teleshopping windows were abolished. Switzerland, however, opted to maintain the provision that advertising spots may not exceed $15 \%$ of the daily transmission time (Directive 2010/13/EU, Art. 23; RTVO 2007, Art. 19 as amended by AS 2010, pp. 965-972). Fourth, the regulation of sponsorship was slightly changed and brought in line with the directive (Directive 2010/13/EU, Art.10; RTVO 2007, Art. 20 as amended by AS 2010, pp. 965-972). Finally, it was decided to adopt the new European provision on product placement which slightly differed from the Swiss rules (Directive 2010/13/EU, Art.11; DETEC, 2009, p. 2; RTVO 2007, Art. 21 as amended by AS 2010, pp. 965-972). These changes entered into force on April 1, 2010.

Despite the fact that there was no obligation to adjust the Swiss regulatory framework to the new advertising rules in the AVMS directive, only few differences to European minimum standards remain. For instance, the ban on political, religious and spirits advertising persists. Driven by the goal to prevent a disadvantage for domestic channels compared to advertising windows on foreign channels, Switzerland essentially adapted to the relevant provisions of the EU's directive.

Table 1 summarizes the different instances of direct and indirect Europeanization in Swiss television regulation since the liberalization of broadcasting. 


\begin{tabular}{|c|c|c|c|}
\hline & & Indirect Europeanization & Direct Europeanization \\
\hline \multirow[t]{2}{*}{$\begin{array}{l}\text { Phase 1: } \\
\text { RTVA 1991 }\end{array}$} & EU & $\begin{array}{l}\text { - Permission of commercial } \\
\text { breaks } \\
\text { - Adaptation of time limits for } \\
\text { advertising to TWF/ECTT } \\
\text { - Adoption of TWF/ECTT sponsor- } \\
\text { ship rules } \\
\text { - Adoption of TWF/ECTT waiting } \\
\text { period for films }\end{array}$ & - \\
\hline & $\mathrm{CoE}$ & $\begin{array}{l}\text { - Permission of commercial } \\
\text { breaks } \\
\text { - Adaptation of time limits for } \\
\text { advertising to TWF/ECTT }\end{array}$ & $\begin{array}{l}\text { - Abolishment of ban on foreign } \\
\text { channels that do not comply } \\
\text { with Swiss advertising rules } \\
\text { from cable networks } \\
\text { - Permission of free reception of } \\
\text { TV signals from telecommunica- } \\
\text { tions satellites (in response to } \\
\text { ECHR judgment in Autronic } \\
\text { case) } \\
\text { - Adoption of TWF/ECTT sponsor- } \\
\text { ship rules } \\
\text { - Adoption of TWF/ECTT waiting } \\
\text { period for films }\end{array}$ \\
\hline \multirow{2}{*}{$\begin{array}{l}\text { Phase 2: } \\
\text { Failed acces- } \\
\text { sion to EEA }\end{array}$} & EU & $\begin{array}{l}\text { - Non-discrimination of foreign } \\
\text { broadcasters }\end{array}$ & - \\
\hline & $\mathrm{CoE}$ & - & - \\
\hline \multirow[t]{2}{*}{$\begin{array}{l}\text { Phase 3: } \\
\text { ECTT/ TWF } \\
\text { revisions }\end{array}$} & EU & $\begin{array}{l}\text { - Adoption of TWF/ECTT access } \\
\text { to major events provision } \\
\text { - Abolishment of waiting period } \\
\text { for films }\end{array}$ & - \\
\hline & $\mathrm{CoE}$ & $\begin{array}{l}\text { - Adoption of TWF/ECTT access } \\
\text { to major events provision } \\
\text { - Abolishment of waiting period } \\
\text { for films }\end{array}$ & - \\
\hline \multirow[t]{2}{*}{$\begin{array}{l}\text { Phase 4: } \\
\text { MEDIA Plus }\end{array}$} & EU & - & $\begin{array}{l}\text { - Adoption of TWF quotas for } \\
\text { European and independent pro- } \\
\text { ductions (as part of "MEDIA } \\
\text { Plus" agreement) }\end{array}$ \\
\hline & $\mathrm{CoE}$ & - & - \\
\hline
\end{tabular}

Table 1: Europeanization of Swiss broadcasting regulation. 
Indirect Europeanization

\begin{tabular}{|c|c|c|c|}
\hline \multirow[t]{2}{*}{$\begin{array}{l}\text { Phase 5: } \\
\text { RTVA } 2006\end{array}$} & EU & $\begin{array}{l}\text { - Adaptation of commercial } \\
\text { breaks regulation to TWF/ECTT } \\
\text { - Adaptation of time limits for } \\
\text { teleshopping to TWF/ECTT } \\
\text { - Abolishment of ban on beer/ } \\
\text { wine advertising for local/ } \\
\text { regional TV } \\
\text { - Adoption of TWF protection of } \\
\text { minors provision }\end{array}$ & - \\
\hline & $\mathrm{CoE}$ & $\begin{array}{l}\text { - Adaptation of commercial } \\
\text { breaks regulation to TWF/ECTT } \\
\text { - Adaptation of time limits for } \\
\text { teleshopping to TWF/ECTT } \\
\text { - Abolishment of ban on beer/ } \\
\text { wine advertising for local/ } \\
\text { regional TV } \\
\text { - Adoption of ECTT general obli- } \\
\text { gations for broadcasters }\end{array}$ & $\begin{array}{l}\text { Narrower definition of political } \\
\text { advertising (in response to } \\
\text { ECHR judgment in } \operatorname{VgT} \text { case) }\end{array}$ \\
\hline \multirow[t]{2}{*}{$\begin{array}{l}\text { Phase 6: } \\
\text { MEDIA } 2007\end{array}$} & EU & $\begin{array}{l}\text { - Abolishment of ban on beer/ } \\
\text { wine advertising for all chan- } \\
\text { nels }\end{array}$ & $\begin{array}{l}\text { - Acceptance of state of transmis- } \\
\text { sion principle and adoption of } \\
\text { TWF access to major events pro- } \\
\text { vision (as part of "MEDIA 2007" } \\
\text { agreement) }\end{array}$ \\
\hline & $\mathrm{CoE}$ & - & - \\
\hline \multirow[t]{2}{*}{$\begin{array}{l}\text { Phase } 7: \\
\text { AVMS directive }\end{array}$} & EU & $\begin{array}{l}\text { - Adaptation of advertising } \\
\text { regulation to AVMS }\end{array}$ & - \\
\hline & $\mathrm{CoE}$ & - & - \\
\hline
\end{tabular}

Table 1: Continued from page 408.

\section{Discussion and conclusion}

This paper explored the Europeanization of television regulation in non-EU member states. In response to a new era of transfrontier television brought about by liberalization and advances in distribution technology, both the Council of Europe and the EU became active in television regulation. Community law affects not only members of the EU but also non-members, yet to varying 
degrees. Other than acceding countries and EEA members (e.g., Norway), Switzerland has no obligation to adapt to the acquis communautaire. Findings suggest that Swiss television regulation was indeed heavily influenced by European audiovisual policy but Europeanization differed strikingly from that in other nonmember states.

On the one hand, Switzerland had an interest in concluding the bilateral "MEDIA Plus" and "MEDIA 2007" agreements in order to improve the support of its audio-visual industry. In exchange for participation in the MEDIA support programs, Switzerland had to transpose quota regulations, a provision granting access of the public to events of major importance and the highly controversial state of transmission principle contained in the TWF and AVMS directives. Additionally, it was necessary to adhere to certain provisions of the ECTT when preparing the first RTVA of 1991 and to slightly adjust legislation to judgments of the ECHR. Hence, the first proposition that direct Europeanization played a marginal role can be partly uphold. However, the acceptance of the state of transmission principle involves a significant shift in Switzerland's relationship to the EU, as will be discussed below.

On the other hand, indirect Europeanization by autonomous adaptation led to revisions and adjustments of Swiss television regulation time and again. Out of economic interests, provisions for television advertising were deregulated in response to liberalization at the European level. The empirical analysis thus supports the second proposition that autonomous adaptation is important when it comes to advertising regulation. Yet, as expected, the nature of indirect Europeanization changed after the entering into force of the new AVMS directive which liberalized advertising regulation in the EU. The analysis corroborates the third proposition that compatibility with EU regulations gained in importance. Switzerland autonomously adapted to the liberal advertising provisions of the AVMS directive. However, unlike proposed, it was not locational policy that prompted Switzerland to level down its advertising regulation to the minimum standards of the directive. Rather, the acceptance of the state of transmission principle caused by direct Europeanization was a turning point with severe consequences for indirect Europeanization as it rendered void the favorable ECTT provision dealing with advertising windows. Before, advertising windows on foreign channels directed at Swiss viewers were not allowed to circumvent Swiss advertising regulation. Reverse discrimination existed only in the sense that commercial channels abroad potentially had better economic conditions. After, advertising windows have to comply with the regulation in their respective countries of origin alone, and stricter Swiss regulation only applies to domestic channels. As a consequence, the pressure to autonomously adapt to the AVMS directive's advertising rules has risen in order to prevent a discrimina- 
tion of domestic channels compared to advertising windows on foreign channels.

These results also show that Europeanization was often motivated by economic considerations. Both the participation in the MEDIA support program and the leveling down of existing advertising regulation correspond to the interests of the domestic audio-visual and advertising industry. The argument of a level playing field (gleich lange Spiesse) was used repeatedly to demand less rigid advertising regulation. In the end, Europeanization brought about a marketization of Swiss television: 20 years after the EU and the Council of Europe became active in television regulation, Switzerland is incorporated into a Europe of television advertising without frontier. However, it needs to be emphasized that Switzerland liberalized advertising regulation only reluctantly and following changes at the European level. The RTVA of 1991 contained strict regulations for commercial breaks and prohibited alcohol advertising. Parliament and government were not willing to put locational policy and the competitiveness of the domestic industry completely before the interest of viewers and alcohol prevention. Only 15 years later, with the new RTVA of 2006, the regulation of commercial breaks was liberalized. This prolonged refusal to liberalize advertising regulation was facilitated by the fact that advertising windows had to comply with Swiss regulation. This changed after Switzerland unwillingly accepted the state of transmission principle in exchange for participation in the "MEDIA 2007" program. Only now, in order to prevent a discrimination of domestic broadcasters against advertising windows, alcohol advertising and a further leveling down of regulation to the new minimum standards of the AVMS directive became acceptable to parliament and government. It is thus questionable whether such marketization would have taken place without advertising windows overspilling from less-strictly regulated markets. This reluctance towards liberalization might partly be explained by the weak role commercial broadcasting plays in the small Swiss media system. In contrast to its big neighbors, Switzerland had hardly any reason to push for a marketization of broadcasting.

When compared to both EU member states and other non-members that are required to constantly align to the acquis, it is striking that Europeanization of television regulation in Switzerland is restricted to compliance with the conditions for participation in the MEDIA support programs (i.e., the transposition of the unwanted state of transmission principle and of uncontroversial quota regulations) as well as to the unilateral leveling down of advertising regulation. The more recent regulatory issues that most European countries have to deal with - the regulation of non-linear audio-visual services and ex-ante tests for new services offered by public service broadcasters - do not concern Switzer- 
land at all. Other than EEA countries like Norway, Switzerland is neither obligated to transpose the AVMS directive nor to comply with EU state aid rules. This is not to say that the online activities of the public service broadcaster SRG SSR are undisputed. However, the introduction of a public value test and the application of competition regulation to the funding of SRG SSR prove to be non-issues. It will be interesting to observe whether this Alleingang in regulating video-on-demand and public service media will be sustainable or whether Europeanization is inevitable in the long run.

In conclusion, this study shows how far-reaching the influence of the EU in the broadcasting sector is even for non-member states. Irrespective of differences in the degree of Europeanization, non-member states are formally excluded from EU decision-making. The EFTA countries that joined the EEA, like Norway, constantly have to align to the acquis communautaire. And since accepting the state of transmission principle when concluding the "MEDIA 2007" agreement, Switzerland has virtually no choice but to autonomously adapt to the advertising provisions contained in the AVMS directive in order to prevent a discrimination of domestic commercial television. This raises the question of whether non-membership really is a recommendable strategy to preserve a country's independence or whether the "semi-colonial" quasi-automatic transfer of EU regulations and so-called "autonomous" adaptation are not resulting in a far bigger dependence since rules are adopted without having a say in their development.

\section{References}

Bonfadelli, H., \& Meier, W. A. (1994). Kleinstaatliche Strukturprobleme einer europäischen Medienlandschaft. Das Beispiel Schweiz [Structural problems of small states in a European media landscape. The example of Switzerland]. In O. Jarren (Ed.), Medienwandel - Gesellschaftswandel? 10 Jahre dualer Rundfunk in Deutschland (pp. 69-90). Berlin: Vistas.

Bonfadelli, H., \& Meier, W. A. (2007). Zum Verhältnis von Medienpolitik und Publizistikwissenschaft - am Beispiel Schweiz [The relationship of media policy and communication science - the example of Switzerland]. In O. Jarren \& P. Donges (Eds.), Ordnung durch Medienpolitik? (pp. 37-58). Konstanz: UVK.

Burgelman, J.-C., \& Pauwels, C. (1992). Audiovisual policy and cultural identity in small European states: The challenge of a unified market. Media, Culture \& Society, 14(2), 169-183.

Dumermuth, M. (2007). Rundfunkregulierung - Alte und neue Herausforderungen [Broadcasting regulation - old and new challenges]. In O. Jarren \& P. Donges (Eds.), Ordnung durch Medienpolitik? (pp. 351-397). Konstanz: UVK.

Dyson, K., \& Humphreys, P. (1989). Deregulating broadcasting. The West European experience. European Journal of Political Research, 17(2), 137-154. 
Egebert, M., \& Trondal, J. (1999). Differentiated integration in Europe: The case of EEA country, Norway. Journal of Common Market Studies, 37(1), 133-142.

Hallin, D. C., \& Mancini, P. (2004). Comparing media systems. Three models of media and politics. Cambridge: Cambridge University Press.

Harcourt, A. (2005). The European Union and the regulation of media markets. Manchester: Manchester University Press.

Harrison, J., \& Woods, L. (2007). European broadcasting law and policy. Cambridge: Cambridge University Press.

Humphreys, P. (1996). Mass media and media policy in Western Europe. Manchester: Manchester University Press.

Künzler, M. (2009). Die Liberalisierung von Radio und Fernsehen. Leitbilder der Rundfunkregulierung im Ländervergleich [The liberalization of radio and television. Guiding principles of broadcasting regulation in comparison]. Konstanz: UVK.

Künzler, M., \& Schade, E. (2007). Schafft Politik eine Medienordnung? Eine komparative Analyse deutscher, österreichischer und schweizerischer Medienpolitik seit 1945 [Is policy creating a media order? A comparative analysis of German, Austrian and Swiss media policy since 1945]. In O. Jarren \& P. Donges (Eds.), Ordnung durch Medienpolitik? (pp. 83-107). Konstanz: UVK.

Kux, S., \& Sverdrup, U. (2000). Fuzzy borders and adaptive outsiders: Norway, Switzerland and the EU. Journal of European Integration, 22(3), 237-270.

Lavenex, S., Lehmkuhl, D., \& Wichmann, N. (2009). Modes of external governance: A crossnational and cross-sectoral comparison. Journal of European Public Policy, 16(6), 813833.

Levy, D. A. L. (1999). Europe's digital revolution. Broadcasting regulation, the EU and the nation state. London: Routledge.

Mach, A., Häusermann, S., \& Papadopoulos, Y. (2003). Economic regulatory reforms in Switzerland: Adjustment without European integration, or how rigidities become flexible. Journal of European Public Policy, 10(2), 301-318.

Mason, J. (2002). Qualitative researching (2nd ed.). London/Thousand Oaks/New Delhi: Sage. Mayring, P. (2007). Qualitative Inhaltsanalyse. Grundlagen und Techniken (9 $9^{\text {th }}$ ed.). Weinheim: Beltz.

Meier, W. A. (1993). Neue Medien in der Schweiz: ihre Zielsetzungen und Leistungen [New media in Switzerland: their objectives and accomplishments]. In W. A. Meier, H. Bonfadelli \& M. Schanne (Eds.), Medienlandschaft Schweiz im Umbruch. Vom öffentlichen Kulturgut Rundfunk zur elektronischen Kioskware (pp. 203-270). Basel: Helbing \& Lichtenhahn.

Meier, W. A., \& Trappel, J. (1992). Small states in the shadow of giants. In K. Siune \& W. Truetzschler (Eds.), Dynamics of media politics. Broadcast and electronic media in Western Europe (pp. 129-142). London/Newbury Park/New Delhi: Sage.

Michalis, M. (2007). Governing European communications. From unification to coordination. Lanham: Lexington Books.

Moe, H. (2010). Governing public service broadcasting: "Public value tests" in different national contexts. Communication, Culture \& Critique, 3(2), 207-223.

Puppis, M. (2009). Introduction. Media regulation in small states. International Communication Gazette, 71(1-2), 7-17.

Saxer, U. (1989). Lokalradios in der Schweiz. Schlussbericht über die Ergebnisse der nationalen Begleitforschung zu den lokalen Rundfunkversuchen 1983-1988 [Local radio in 
Switzerland. Final report on the results of the scientific evaluation of local broadcasting tests 1983-1988]. Zürich: Seminar für Publizistikwissenschaft.

Schneider, V., \& Werle, R. (2007). Telecommunications policy. In P. Graziano \& M. Vink (Eds.), Europeanization: New research agendas (pp. 266-280). Basingstoke: Palgrave Macmillan.

Schimmelfennig, F., \& Sedelmeier, U. (2004). Governance by conditionality: EU rule transfer to the candidate countries of Central and Eastern Europe. Journal of European Public Policy, 11(4), 661-679.

Sciarini, P., Fischer, A., \& Nicolet, S. (2004). How Europe hits home: Evidence from the Swiss case. Journal of European Public Policy, 11(3), 353-378.

Siegert, G. (2006). The role of small countries in media competition in Europe. In J. Heinrich \& G. G. Kopper (Eds.), Media Economics in Europe (pp. 191-210). Berlin: Vistas.

Syvertsen, T. (2003). Challenges to public television in the era of convergence and commercialization. Television \& New Media, 4(2), 155-175.

Trappel, J. (1991). Born losers or flexible adjustment? The media policy dilemma of small states. European Journal of Communication, 6(3), 355-371.

Wheeler, M. (2004). Supranational regulation. Television and the European Union. European Journal of Communication, 19(3), 349-369.

Zeller, F., \& Ramsauer, M. (2010). Neue Regeln für audiovisuelle Abrufdienste: Ins Stocken geraten [New rules for audiovisual on-demand services: slowing down]. BAKOM Infomailing, (21). Retrieved July 4, 2012 from http://www.bakom.admin.ch/ dokumentation/Newsletter/01315/03452/03456/index.html?lang=de.

\section{Analyzed documents}

Case of Autronic AG v. Switzerland (Application 12726/87). Strasbourg, 22 May 1990.

Case of VgT Verein gegen Tierfabriken v. Switzerland (Application 24699/94). Strasbourg,

28 June 2001.

DETEC (2007): Explanatory notes to RTVO 2007.

DETEC (2009): Explanatory notes to RTVO revision.

Directive 2010/13/EU of the European Parliament and of the Council of 10 March 2010.

Official Journal L 95, 15 April 2010, 1-24.

Directive 89/552/EEC of 3 October 1989. Official Journal L 298, 17 October 1989, 23-30.

Directive 97/36/EC of the European Parliament and of the Council of 30 June 1997 amending Council Directive 89/552/EEC. Official Journal L 202, 30 July 1997, 60-70.

European Convention on Transfrontier Television (ECTT). Strasbourg, 5 May 1989. Text amended according to the provisions of the Protocol (ETS No. 171), which entered into force on 1 March 2002.

Federal Council (1987): Dispatch to RTV Bill 1987. BBl 1987, 3(47), 689-754.

Federal Council (1990): Dispatch to ECTT. BBl 1990, 3(47), 925-968.

Federal Council (1992): Additional dispatch II to EEA Dispatch. BBl 1992, 5(35), 520-837.

Federal Council (1993): Dispatch after rejection of EEA Agreement. BBl 1993, 1(11), 805-994.

Federal Council (1999): Dispatch to ECTT Revision. BBl 2000, 1(10), 1291-1303.

Federal Council (2000a): Discussion paper on the RTVA revision.

Federal Council (2000b): Explanatory notes to RTV Draft 2000. 
Federal Council (2002): Dispatch to RTV Bill 2002. BBl 2003, 1(8), 1569-1778.

Federal Council (2004): Dispatch to Bilateral Agreements II between Switzerland and the European Union. BBl 2004, 1(44), 5965-6300.

Federal Council (2007): Dispatch to Bilateral MEDIA 2007 Agreement. BBl 2007, 1(41), 66816694.

Federal Council (2008): Additional Dispatch to Bilateral MEDIA 2007 Agreement. BBl 2008, 1(50), 9105-9124.

MEDIA 2007 Agreement between Switzerland and the European Community. AS 2007, 50, 6953-6966.

MEDIA Plus Agreement between Switzerland and the European Community. AS 2006, 12, 1041-1056.

Official Bulletin of the Council of States [Amtliches Bulletin des Ständerates, AB S] AB S 1990, 562-620; AB S 1991, 423-430, 506-507; AB S 1992, 658-659; AB S 1993, 193; AB S 2000, 223-224; AB S 2004, 662-689; AB S 2005, 44-103, 187-204, 932-943; AB S 2006, 91-94; AB S 2007, 1013-1018; AB S 2009, 233-242, 447-450, 914-916, 972.

Official Bulletin of the National Council [Amtliches Bulletin des Nationalrates, AB N] AB N 1989, 1587-1657, 1660-1684; AB N 1991, 334-356, 1104-1107, 1153-1154; AB N 1992, 1972-1976; AB N 1993, 811-812; AB N 2000, 796-797; AB N 2004, 35-156, 426-434, 1904-1928; AB N 2005, 1108-1130, 1275-1286; AB N 2006, 2-11; AB N 2007, 1854-1859; AB N 2009, 876-895, 1577-1581, 1702-1703, 1781.

Radio and Television Act (RTVA) 1991. AS 1992, 11, 601-626. Amended by AS 1993, 51, 33543356 and $A S$ 2006, 12, 1039-1040.

Radio and Television Act (RTVA) 2006. AS 2007, 12, 737-786. Amended by AS 2010, 3, 371372.

Radio and Television Bill (RTV Bill) 1987. BBl 1987, 3(47), 755-778.

Radio and Television Bill (RTV Bill) 2002. BBl 2003, 1(8), 1779-1831.

Radio and Television Draft (RTV Draft) 2000.

Radio and Television Ordinance (RTVO) 1992. AS 1992, 13, 680-711. Amended by AS 1993, 51, 3357-3365.

Radio and Television Ordinance (RTVO) 1997. AS 1997, 49, 2903-2922. Amended by AS 1999, 29, 1845-1847 and AS 2006, 12, 959-960.

Radio and Television Ordinance (RTVO) 2007. AS 2007, 12, 787-820. Amended by AS 2010, 11, 965-972.

\section{List of abbreviations}

\section{AVMS Audiovisual Media Services}

CoE Council of Europe

DETEC Federal Department of the Environment, Transport, Energy and Communications

ECHR European Court of Human Rights

ECTT European Convention on Transfrontier Television

EEA European Economic Area

EFTA European Free Trade Association

EU European Union

RTVA Radio and Television Act 
RTVO Radio and Television Ordinance

TWF Television without Frontiers 